\title{
THE NARRATIVES OF OSKAR LOORITS AND PAUL ARISTE AND THEIR PROBLEMATIC DIALOGUE WITH THE 'POPULAR'
}

\author{
Madis Arukask
}

\begin{abstract}
The topic of this paper is the dialogue of the 'popular' and 'individual', more precisely the role of two outstanding persons in trying to help find the sense of ethnic identity and working towards the establishment of the national identity of two ethnic groups in the 20th century. The paper deals with the Estonian and Votian peoples and respectively the contributions of Oskar Loorits (1900-1961), the Estonian folklorist, and Paul Ariste (1905-1990), the Estonian linguist, to the development of the nationalist sentiment of both nations. The article addresses the choices made by them when compiling their more or less ideological writings, as well as their endeavours, controversies and personal qualities and period backgrounds, eventually the supposed reception of their message by the target groups - the Estonians and the Votes -, as well as the reflections of their ideas in our time.
\end{abstract}

Key words: Estonian folk culture, ethnic history, national identity, Votian folk culture

\section{INTRODUCTION}

The present paper discusses the dialogue between the popular and the individual, more precisely the role of two eminent persons in shaping the problems of nationality and national identity among two ethnic groups in the 20th century. The groups in question are defined by the relatively inaccurately delimited, but popularly agreed term 'peoples'. The focus here is on the Estonian and the Votian people(s), and on the influence of two eminent Estonian scholars of the 20th century, Oskar Loorits (1900-1961) and Paul Ariste (1905-1990) respectively, as shapers of national opinion. The choices made by Loorits and Ariste in composing their more or less ideological narratives, their aspirations and contradictions, personal qualities and period backgrounds, and eventually also the supposed reception of their message by the target groups - by the Estonian and the Votian people - will be examined, as well as the more mod- 
ern attitudes towards their ideas, or rather the reflections of their ideas in our time.

The 'popular' will here be understood as a statement about local knowledge, essentially opposed to the categorizations created by analytical thinking, or in other words,

religion rests its case on revelation, science on method, ideology on moral passion; but common sense rests its on the assertion that it is not a case at all, just life in a nutshell. The world is its authority. (Geertz 1983: 75)

The hypothetical assumption will be that if the 'expert voice', pushed into a mental or material position of force by ideological, political, economic or other passions, begins to dominate over the inert consciousness of the people - the 'popular wisdom' - and to significantly shape it, this points to an either already present or imminent identity crisis, to a confusion concerning one's own ethnic group affiliation, and a readiness to comply with whatever the external authority offers. In such a situation, 'authority' is thus not construable as mere (ethnic, etc.) 'other', but may just as well be a person of the same ethnicity, harbouring the best intentions, who either deliberately or unwittingly is trying to put into practice or instil his own ideal vision and expectations.

It is obvious that the study of folk culture in 20th-century Estonia was clearly dominated by the aftereffects of a Herderian Romanticist view, somewhat idealizing the simple (country) person or landfolk, yet at the same time craving to distil a 'national' essence from it. Such a viewpoint forms a natural basis for class differentiation between the affiliations of the investigator and his object, an attitude notable both in Loorits's and in Ariste's work. At the same time, the desire and aspiration to identify oneself either directly or wishfully with the studied people - in Loorits's case, naturally, with Estonians, in Ariste's case (as incredible as it may seem) with Votes - is to be felt in both cases. In addition to the Herderian idealizing, however, another factor must be taken into account in the given cases, a factor closer to our main concern here: just like the people have shaped/are shaping the attitudes and views of the authority, so does the authority ever more progressively attempt to do the same with those of the people. It is not just the mental heritage, folklore, etc. that is being attempted to be salvaged, but the people (and its self-definition) itself. 


\section{THE DIFFERENCES AND SIMILARITIES OF POINTS OF DEPARTURE}

At present, Estonians constitute a modern nation with about 1.5 million native speakers, the existence of which has been supported (apart from the periods of Soviet and German occupations) by the Republic of Estonia, founded in 1918. Yet the history of Estonians as a modern nation is not very long. A decisive turn towards nationhood took place in the second half of the 19th century, primarily in connection with the cultural emancipation going on in the two Baltic provinces of the then Tsarist Russia dominated by Baltic German élite: an emancipation that finally led to independent statehood in the 20 th century. At the same time this relatively intense leap away from a predominantly local peasant culture towards a structured civil society did not automatically imply consensus on several philosophical issues of nationality - and this constitutes the main theme of the present article. The dialogue between 'nation' and 'people' has been obviously going on in Estonian culture, up to the present.

The Votes are (or were) the Estonians' closest linguistic relatives, whose historical homeland lay to the east of Estonia; in recent centuries they have inhabited the historical Ingermanland on the southern coast of the easternmost part of the Gulf of Finland. ${ }^{1}$ Unlike that of the Estonians, the Votes' national destiny has involved not cultural emancipation, but assimilation, meaning that in the nearest future, it will be more correct to use the past tense when speaking about them. Currently, there are only a few old people left in the Peski, Luzhitsy and Krakol'e villages in Kingisepp region, Leningrad Oblast, Russia, who still speak Votian as their mother tongue. Thus, at the beginning of the 20th century the Estonian and Votian peoples were at very different stages of their formation, and, accordingly, out of balance as objects of study. Their choice for discussion in the present paper was occasioned only by the two personages mentioned above.

Very likely the (North) Estonians and the Votes have originally formed one ethnos, the speakers of the "dialect of the land" (Est. maamurre; cf. Rätsep 1989: 1505ff) which belonged to the Southern group of Balto-Finnic languages. Beginning in the 13th century, against the backdrop of the Teutonic Order, the Christian invasion from Denmark and Sweden, and the subsequent conquest of the then Estonian territory, the mutual contacts between Estonians and Votes grew sparser, primarily for reasons associated with politics and statehood, and it is particularly from then on that the Votes became unidirectionally isolated under the influence of Russian (and Orthodox Church) cultural space. ${ }^{2}$ 
This analysis, however, does not comprise these Votes who in all likelihood still inhabited the Northeast and East Estonia for several centuries to come, assimilating over time into the Estonian population.

In written histories of Estonia, the period of Swedish dominance between the great wars of the 17th and, circumstantially, also the beginning of the 18th centuries, can be pointed out as an important chapter in the formation of Estonian identity, a period when more democratic processes began to gain ground in the society and when the legalization of Lutheranism by the state created favourable conditions for the spread of Christianity and the written word in the local native language. It is true that no eminent enlighteners of Estonian origin were born in Estonia at that time, who would have begun to integrate the Western élite culture with the local one; nevertheless, it is precisely the 'Swedish time' that has tirelessly been recalled in positive terms, both by historians and in popular discourse (cf. the metaphor of the 'golden' or 'good old' Swedish time; cf., e.g., Jackson 1948: 54ff, Laar 2006: 62 ff, also Loorits 1932b: 25-26). Naturally this idealizing vision of the Swedish domination is based on its political contrast with the expansions of the Russian empire, whereas in folk (folkloric) treatment it appears to be grounded - obliviously of the fact that in those days, the common people were maltreated by all conquerors - on resistance offered to the marauders that had always raided the country from the east.

The historical opposition of Sweden and Russia in the history of Estonia/ Estonians, which forced the people to take sides, is adjacent to another basic and, by now, more completely forgotten opposition between the German landlords and the landfolk (maarahvas) - an opposition which, however, will probably have been equally or even more important for the Estonians at least up to the War of Independence (1918-1920) that led to the factual independence of the Estonian state. While the Swedish time and accounts of descent or migration touching upon it are remembered in the popular tradition (through family lore, for instance - cf. ancestors of Swedish origin, Jaago \& Jaago 1996: 50-53), the axis of opposition between the Germans and the landfolk was either reactualized for national-romanticist reasons in the 19th-century period of awakening, or had been based throughout centuries on social antagonism and class hatred. The popular hostility towards Germans that had played an important role in the formation of the Estonian identity was brought to an end mainly by the departure of the Baltic Germans as a result of the secret agreements between Hitler and Stalin, in 1939, which left Estonia into the Soviet Union's sphere of interest and presently led to her annexation by the Red Army. Particularly the events in Estonia of 1941, at the beginning of the Second World 
War, caused the people to feel an extraordinary antipathy towards the Soviet/ Russian power and mentality, the effects of which must be recognized even up to the present.

Among the Votes, persisting signs of a past self-definition are notably sparser. In Russian Orthodox environment (de iure since the Christianization of Russia and the days of the Princely State of Novgorod at the beginning of the previous millennium, de facto perhaps only since the missions of the 16th century, and to a limited extent - cf. also Viikberg 2001: 359-360; Västrik 2007: 44ff), the Votes' self-definition became increasingly religion-centred, particularly by the 20th century; it was rather common to regard oneself as Russian (cf. Ariste 2005: 27, 30-31). Nevertheless, the ethnonyms 'Vote' and 'landfolk' have always been used as well. ${ }^{3}$ The Votian identity has been constantly levelled over the last century. One reason for this could be ethnic mimicry - presenting oneself as somebody else, depending on the situation; perhaps it may also be caused by the Votes' more innovative attitude and readiness to integrate into a globalizing world. With the foundation of St Petersburg, the capital-to-be of the Russian empire, in their vicinity at the beginning of the 17th century, the Votes were drawn into the currents of globalism and early modernity far earlier than the Estonians, and their mentality began to be shaped by trade relations with the metropolis and the innovations resulting from it. ${ }^{4}$

Like Estonians, the Votes, too, have an element of Swedish identity in their traditional self-narrative. They have called themselves 'the Swedish people', and that popular knowledge derives from the period when Ingermanland belonged to Sweden, from the Stolbovo peace treaty (1617) up to (de facto) 1703, when Russia reclaimed the area. Regardless of the ever increasing identification with Russianness, the element of Swedish identity has been remembered by even the last speakers of Votian in the present time. In certain situations, this has been used to emphasize one's difference from the general, predominantly Russian milieu. In the Votian as well as the Estonian popular tradition, the Swedish element has been activated in people's consciousness by certain physical objects on the landscape, like distinctive old stone crosses or oldentime graveyards, which among the Votes, for instance, have been called šveda kalmod ('Swedish graves'; a similar name for old village graveyards is known in Estonia). From the popular viewpoint, it does not matter very much that the crosses may originate from a much earlier time, not at all associated with the Swedes.

Over the last centuries, the Votes' self-consciousness has been in a defensive position, psychologically expressed, among other things, by a desire to forget (or deny) their ethnic belonging - a feature certainly observable among 
many small nations of the world that have either drifted or been forced into the cultural periphery. By the middle of the 20th century, the Votian-Russian double identity that had apparently begun to expand from the 19th century onwards had undergone a rather remarkable change: As a result of both the Soviet national policies and the deportations and flights during and after the Second World War, the element of Votian identity came to be decisively concealed, forgotten or denied among themselves. In (Soviet) Russia, the Votes became Russians quite voluntarily; ${ }^{5}$ the Votes who arrived and stayed in Estonia after the last war, with the wave of refugees from Ingermanland, identified themselves, depending on their environment, as either Russians or Ingrian Finns. Such largely conscious and often painful renouncing of one's roots to conform to the social reality has also been the lot of many small nations under the Soviet regime and, for the Votes, even before that. While Feodor Tumanski in his 17th century travel accounts mentions, when discussing the Votes, at least (a traditionally handed down) memory of their heroic past (cf. Öpik 1970: 85), in later stages of acculturation this knowledge of the past becomes ever more rarely "usable" - a thing pointed out only sporadically and in specific situations.

Whereas the Estonians' 'landfolk period' seems to have passed relatively smoothly, via the cultural bridges and ruptures of the time of awakening into (Great-) Estonian nationalism, among the Votes it caved in upon itself, giving, as a by-product, physical addition to (Great-) Russian nationalism. At such turning points, it is always interesting to observe what kind of choices get taken along from a pre-modern past into a more 'grown-up' national present. Building up a national civil state, the Estonians turned part of their traditional culture into an emblematic part of the nation state, whereas the rest of it was explicitly or implicitly declared unfit. The revision of traditional culture and efforts to disentangle themselves from their peasant past in order to embrace a new, 'European' one were visibly hurried, and the corresponding critical reaction did not take long to set in.

\section{OSKAR LOORITS (1900-1961)}

Oskar Loorits was Estonian folklorist and publicist whose contribution into the development of Estonian folklore studies is noteworthy. He was one of the founders of the Estonian National Folklore Archives in 1927, and served as its first director; from the same year, he also held the position of a lecturer at the University of Tartu. In 1939, he became Professor of Estonian and Comparative Folklore at the University of Tartu. In 1944, he managed to escape from 
the occupying power and reach Sweden, where he continued his research work (for a closer look at Loorits's activities, see Tedre 1995; also Västrik 2005). In exile, Loorits published his perhaps the most fundamental work (besides his earlier articles and monographs) on Estonian folklore - the monumental threevolume treatise of Estonian folk beliefs, Grundzüge des estnischen Volksglaubens (1949; 1951; 1959-1960). Not less noteworthy is his research of the Livonian folklore. In this field, his multi-volume Liivi rahva usund ('Livonian Folk Religion', 1926; 1927; 1928; the two last volumes remained unpublished during his life), deserves notice above other works. The aim of the present article, however, is not so much to focus on Loorits's research as on Loorits as a national ideologist. Nevertheless, it must be noted that while studying the folk culture of the Livonians, Loorits also acted there as an ideologist, being a thorn in the side of the then government of the Republic of Latvia. Naturally, it would have been intriguing to study Loorits's nation-building work among the Livonians as a small nation, especially compared to Ariste and his activities among the Votes.

Undoubtedly, Oskar Loorits is one of the thinkers and activists whose tenets are particularly cherished in modern Estonia, by

(1) apologists of the Estonians as a forest people, a people living in a state of nature;

(2) advocates of 'Finno-Ugrianism' as opposed to 'Indo-Germanicism';

(3) those interested in and supportive of a "racially pure" and vigorous Estonianhood.

Indeed, these three are the pervasive ideas in Loorits's work and are expressed also in his book Eestluse elujõud ('The Vitality of Estonianhood' Loorits 1951), addressed to a wider audience, but also in his other writings. ${ }^{6}$

The first idea evokes in the mind the forest belt of North Eurasia, unfolding before the Finno-Ugrians during their millennia-long movement to the west from the Urals; the second idea is that all mental and physical ills in the life and nature of contemporary Estonians derive from their contacts with the Indo-Germans; a key concept of the third might be the peculiar collective nature of the Estonians as an ancient people of the east, the gist of 'the Northern spirit' (see Loorits 1938a: 222, 228-229; 1951: 36ff). In his ideological writings, Loorits was occasionally capable of looking for and finding arbitrary proof of his statements, something that a scholar cannot afford to do in his intellectual work. This kind of purposeful approach is distinctive of his publications on current affairs and was reportedly also characteristic of his person.

No doubt, Loorits courageously antagonized some significant and politically correct commonsensical or (opportunistically) political (half-)truths, in 
the context of both his contemporary and present-day Estonia. One of the more notable of them would perhaps be his drawing the borderline between the cultural spaces of the East and the West not onto the Narva River or Lake Peipsi (on Estonia's eastern border which by now is also the eastern border of the European Union), but onto the Baltic Sea (Loorits 1936: 162; 1938a: 220), as a result of which Estonians would definitely not be considered Europeans. In Loorits's treatment, this was the geopolitical cornerstone of Estonians as an originally oriental nation. Amongst all Indo-Germans, it was, according to Loorits, primarily the Germanic/Scandinavian nations that had corrupted the Estonians' Finno-Ugric mentality; sympathizing with the Livonians he might add also the Baltic nations/Latvians; and perhaps far less the Slavs/Russians (cf. Loorits 1932a; 1933b).

No doubt Loorits was one of those for whom hostility towards the Baltic Germans was no abstract play of thought but rather a concrete act (cf. 1933b; 1938a: 225). Mental descendants of the introducers of Western Christianity, they certainly did not, for Loorits, construe as 'introducers of culture' but rather as narrow-minded degenerates. Being a folklorist, Loorits knew well the Estonian oral tradition and held up as an ideal its poetic and spiritual richness and central ideas. Everything evil, all fears and phobias in it came either from the contact with conquering Christianity or from an earlier (North-) Germanic world view set about to demonize nature (Loorits 1932a: 9; 1932b: 30ff, 70ff; 1951: 99ff). Besides, Loorits also revised, with characteristic selfconfidence, the prevalent view of the Swedish rule relatively well remembered in popular traditions. He described the period of witch trials and an increasingly systematic Christian brain-washing, under the aegis of the Reformation, as evidence of the bias of the idealistic popular memory which had been based mainly on comparison with even darker periods of history (e.g., Loorits 1951: 103ff). Spitefulness and the 'Estonian obstinacy' as symbols of contemporary Estonian narrow-mindedness originated, in Loorits's view, precisely in the cultural shocks of the Swedish period.

No doubt, one can agree with Loorits on this issue: the popular view of history may in this point indeed be relatively tendentious and selectively unobjective. On the other hand, however, it is equally possible to question Loorits's ability to differentiate, while estimating the sources of mental malaise - why should the characteristically Finno-Ugric forest "melancholy" and the excessive sentience arising from it be "better" than the ill-becoming cultural influences received from the Germanic peoples? What is there good or more characteristic in the arguably original unruliness of the wedding customs which became increasingly regulated as a result of the contact with IndoGermans, as it were, of northern sobriety? Why must the figures of an un- 
friendly revenant or of treasure-bringing demons be of foreign, not local origin? And so on.

A recurrent theme in Loorits's work was either explicitly or implicitly associated with the question of social structure. Here, too, ends could often justify means. Finno-Ugric society was described by Loorits as essentially a democracy, relatively unstructured hierarchically, with the leaders playing very much the role of the servants rather than rulers and governors of the people (Loorits 1951: 58ff). Although the Viking era with its Scandinavian influences (as well as later periods of history) added new notions in this area, these influences never added up to more than the formation of a 'gangocracy' (Loorits 1951: 89ff; also 1934; 1938a: 250ff) - a phenomenon that still afflicted Loorits's contemporary Estonian society before the war as well as in exile. The nonexistence or weakness of Estonian leaders both posed a problem and simultaneously bore witness to the truth of Loorits's theory. Here, it was certainly the Herderian idealization of the spirit of the people which, in its anonymity, could be all the more ideal, that spoke through Loorits's mouth or pen. Paradoxically, Loorits proved unable to avoid the leader's burden himself; with his exhorting tone of a light-bearer he placed himself precisely into the position he questioned. Seeing the prototype of a hero in Jaan Tõnisson, one of the major figures in early 20th-century Estonian politics (Loorits 1933a), he quite obviously set one foot in precisely the track he was trying to distance himself from, when writing. Preaching the ancient pacifist lyrical-epic world as the natural quintessence of the Estonian, he was visibly launching a programmatic offensive himself (cf. Loorits 1938b).

Loorits saw the resources of Estonianhood primarily in the past - in a selective or ideologically 'correctly' commented learning and teaching of the past - , and in a return to it, as seen in the folk tradition. A classical instance is his treatise of proverbs, Muinaseesti unarussejäänud põhiseadusest ('On the Neglected Constitution of Olden-Time Estonia', Loorits 1938c), where the FinnoUgric ideal of love for justice once again found proof, as expected, through the combining of folkloric phraseology. While Tacitus had in his Germania, in AD 98, tacitly criticized the declining Roman society through idealizing the barbarians, Loorits did the same through a comparison of an idealized vision of the Ugrian-Oriental mental history of Estonianhood with his contemporary times and recent past. His uncompromising honesty (or display of it) consisted in the fact that, in his essentially popularizing ideology, he based his views on his personal scholarly positions. Both the researcher and the ideologist had been working inside him from the very beginning at full throttle, and obviously without much conflict - or at least in readiness for mutual compromise. 


\section{PAUL ARISTE (1905-1990)}

As noted above, the cultural corpus of Votianhood was, by the 20th century, irreparably sparser and more hopelessly disintegrating than that of Estonianhood. As such, a comparison of Estonian and Votian cultures would indeed be rather inappropriate - on the one hand, a nation that had reached modernity through the age of national awakening, on the other a universe of memories consisting of archival materials and museal artifacts dissolving within a greater nation. What is interesting here for our present purposes, however, is the connection of the 20th-century Votianhood with the person of Paul Ariste - a man who, one might say, had his own plans for Votianhood.

Paul Ariste was a versatile scholar, first and foremost a linguist (and polyglot), but harbouring interests that spread into various other fields as well. His productivity was no less than that of Loorits, and his linguistic work covered a broad area from phonetics to language contacts. Ariste must be regarded as the founder of the Finno-Ugristic school of research and its practical head for a very long time. In 1944-1946, he was head of the Chair of Estonian and Finno-Ugric languages, in 1946-1977 head of the Chair of Finno-Ugric languages, and from 1949 professor at the University of Tartu. In connection with Loorits and folklore, it may be relevant to point out that before the war Ariste was one of the first full-time researchers at the newly founded Estonian Folklore Archives (1927). He remained interested in folklore and folk culture all through his life, and his many-sided study and introducing of the Votian language and culture (alongside of those of other peoples) undoubtedly offers one of the best instances of this fact. Ariste's research may not have been as monumental as the serial monographs of Loorits on Estonian or Livonian folklore. But his nearly 1,300 scientific publications include numerous corresponding monographs on Votian issues, too - Vadja keele grammatika ('A Grammar of the Votic Language', 1948; in English, Bloomington, 1968), Vadjalane kätkist kalmuni ('A Vote from Cradle to Grave', 1974), Vadja muistendeid ('Votian Legends', 1977), Vadja mõistatusi ('Votian Riddles', 1979), and other books based on language samples and folklore texts collected by himself.

Important differences in the fates of the two men, however, must be pointed out. At the end of the Second World War, Oskar Loorits succeeded in escaping from occupied Estonia into the free world. This determined his further opportunities for voicing his ideological and national standpoints, an activity he, of course, had begun already before the war. Ariste, who remained in Soviet Estonia and made here a far more outstanding academic career than Loorits, naturally lacked this opportunity. His positions on national politics (primarily 
on the Votian example) were sporadic remarks rather than programmatic texts. War-time experiences in the grip of the occupying power taught Ariste lifelong cautiousness, in this respect. Besides, his passion, unlike that of Loorits, was not (besides all else) journalistic, but first and foremost academic. And his style, again unlike that of Loorits, lacked public subjectivity (as well as aggressiveness).

While Loorits was ethnically and naturally born into the 'Estonian cause', Ariste's votophilia was probably generated by a fateful meeting with the Votian singer Daria Lehti, who came from the then Estonian-held villages on the far side of the Narva River, at a concert introducing folk music (arranged by August Pulst) in the Estonia theatre in Tallinn, in 1920 (Ariste 1970: 89). When she was addressed, Lehti had described herself as "an old Vote" (Miä õlonn vana vad'jalain). It is difficult to know whether the singer, aged over 50, may herself have kept the disappearance of her people in mind when using the word old $;^{7}$ at any rate, her alliterative formula made a lasting impression on Ariste. While Loorits may be described as a scholar and ideologist, Ariste could, in connection with the Votian issue, be described as a scholar and mysticist. The latter statement is mainly borne out only by sporadic remarks in his fieldwork diaries and introductions to his publications on Votian issues, as well as by comments dropped to his friends and acquaintances. Ariste was not a Vote, but would have liked to be one. ${ }^{8}$

Of course one cannot rule out the possibility that Ariste's admiration for Votianhood or even Votian identity was supported also by his Northeast Estonian origin, since the forests of Alutaguse and their surrounding areas have ever since prehistoric times been loci of Votian culture contacts and destinations for Votian emigrants. Another factor contributing to the rapport may have been Ariste's Orthodox religious convictions, something that he never let show in Estonia, in his academic life, but could point out during fieldwork, in order to create a closer empathetic bond with his informants by asserting, "I am of the same religion (as you)" (olen (teiega) sama usku, Ariste 2005: 30). Such fragments, but even more the fact that for decades on end, the academician stayed faithfully in the village lanes and farmhouses together with the students and other interested persons, bear out Ariste's single-minded devotion to the study of this vanishing people's language and folklore and his sympathy for such old men and women who still remembered the lost world.

Nevertheless, Ariste's work on Votian issues was not confined to merely romantic or purely academic recording and preserving the language and material culture. On his first expedition to Votian villages, moving east after the front in the warlike summer of 1942, Ariste at first merely observed the fact of 
the Votian language and folk culture being on the verge of extinction. On the following expeditions, however, the question 'Why?' began to emerge ever more vigorously. Like Loorits in the case of Estonianhood and Livonianhood, so was Ariste, too, was not content with the role of a mere observer of processes, but began to shape his informants' convictions while questioning them academically. As a researcher, Ariste dealt mainly with that generation of Votes on whom the Russian social space and education had not yet managed to make a very significant impact. His established network of informants consisted predominantly of illiterate old people born in the last decades of the 19th century. Ariste indeed rejected the younger Votes, as well as the Izhorians and Ingrian Finns that lived all around - that is, other Finno-Ugric ethnic groups who, especially in regard to folk culture and lore, would have offered rich complementary material to the recording of Votian culture, having lived in and shared practically the same cultural space and physical environment with the Votes. Sadly noting in his diaries the increasing remoteness of younger Votes from the more perfect knowledge of language and culture among their elders, he often asked the latter why they had not passed on Votianhood to their children, why they had not taught them the language and mentality from their earliest childhood.

Here it can be said that in a way Ariste continued the idealistic preaching work of earlier Finno-Ugrianists, resistant to any kind of Slavic Indo-Germanness. In our own day, this is in turn continued by modern Estonian, Finnish and Hungarian researchers and politicians who, without thoroughly knowing or wanting to know the daily circumstances of their target group, adapt to it their idealized visions alongside with their disappointment upon sensing the unattainability of these visions, and refuse to accept any responsibility for whatever aftereffect their declarations may have. After all it is very obvious that in many cases, this is no more than a hypocritical advocation of double morals - a representative of a culturally less endangered ethnic group, that is, 'authority', demands of its 'object' behaviours and attitudes he himself would, more often than not, be unable to adopt under similar circumstances. Such an attitude pushes the target into a critical situation - he either stops abruptly to go along with the 'authority', a tactic adopted in the 20th-century Russia's Finno-Ugric context, primarily by men; or he begins to revise his daily attitudes and routines in the direction evoked. The latter course generally proved feasible for old women who had had an empathetic attitude towards their mother tongue since childhood and youth, who, unlike men, had been able to stand somewhat apart from the insolence and influences of the official system of the dominant culture, and who after middle age again found free energy to search for ways of using their natural creativity. 
Ariste's informant network consisted largely of aged women competent in Votian folk culture and finding it, as yet, more natural to communicate in their mother tongue than in Russian even though they had failed to pass on the language to their children (let alone grandchildren). The ethnonym 'Votian' required no reintroduction but a mere reassertion for them that this was the group they still belonged to. Just like in Ariste's view, Votianhood was a matter definable first linguistically and only after that in terms of (folk) culture, so he could presume that reactualizing the people's sense of Votianhood required primarily a knowledge of their mother tongue to serve as the foundation on which to build up their lost world. What with the Votian language lacking, already then, all outlets into the world of official affairs (and by the present, unfortunately, any social dimension at all), the consciousness of Ariste's informants was governed mainly by a Russian-Votian double, or even RussianIzhorian-Votian triple identity that dominated outside the communication situations with Ariste and his students, and remained predominant in daily life.

And still Ariste brought back to the Votian lands the knowledge that Daria Lehti had given him and that persisted there up to the end of the 20th and partially even the beginning of the 21st century - I am a Vote. Certainly the fact that Votian language and culture informants living in the second half of the 20th century identified themselves as Votes can be largely put down to the suggestive influence of Paul Ariste, while the fact of their ascertaining and enunciating it to themselves is a sign of yet another restoration, for a limited time span, of the phenomenon of Votianhood in the global gorge of the world. The individual Votianhood protesting against extinction fed primarily on the person of Ariste; at present, it (although, unfortunately, speaking more and more in Russian) is based on the existence of visiting researchers from Estonia - those who continued Ariste's mission - whose interest in their difference, in the midst of general Great-Russian disinterestedness, the locals find somewhat anomalous and yet encouraging for them to define their cultural distinctiveness, albeit only situationally. For the very few old people still alive who speak Votian as their mother tongue, as well as for the Russian-speaking 'neoVotes' who are carrying out a kind of Votian renaissance through ethno-futuristic acts (symbolics, holding a Votian village feast), Ariste is an idol, a pillar from which to find support (albeit only in memories). 


\section{THE PERSPECTIVES OF LOORITS AND ARISTE}

Both Loorits and Ariste looked first and foremost into the past. Both of them consistently used in their discussion corresponding (alliterative) terms - Loorits had coined the phrase endis-eesti ('the one-time Estonia') ${ }^{\mathbf{9}}$, Ariste vana-vadja ('Old Votian') and ürgvadja ('primordial Votian'). Besides, both men also used the stem muinas- ('olden-time'). Thus, the scholars placed the ideal good old days of the two ethnic and cultural groups somewhere into the past, and both scholars constructed that bygone golden age through a scientific concreteness, a categorization of different elements. Loorits saw real Estonianhood in the semioriental, $U r$-democratic spiritual and political independence of the Old North, as yet uncorrupted by the negative cultural influence of the Germanic tribes and other Indo-Germans, by 'gangocracy' and the narrow-mindedness of leaders. Ariste's concept of primordial Votianhood (see also Arukask 2003) was, in a sense and for understandable reasons, somewhat simpler, antagonizing the Soviet period, the Russian language and (regardless of all also) the Christian worldview. For both men, it was primarily their contemporary women who could be regarded as carrying on such ideals - Loorits definitely mentioned the Estonian woman as a transmitter of culture positively more often than the Estonian man, who was prone to reduce himself to a leader, robber, or hero. For Ariste, the last old Votes (besides Daria Lehti) were primarily the old women-seers in command of folk wisdom, songs and incantations, and his long-term informant Oudekki Figurova ranked first among them.

The Votian present indicated to Ariste, on a daily basis, the loss of all this and it did so ever since his first field trip in 1942. Visions of any future were banned by a sense of reality, an understanding that the Votian golden age would never return. Thus, the only opportunity left to Ariste was to inculcate into the last Votian speakers personal resistance to the onslaught of Russianhood. In this respect, Loorits's expectations for the future and his corresponding narratives were more hopeful, programmatic and ideological. Particularly while in exile, he was able to develop them more freely, unconstrained by the restrictions imposed on his homeland by the totalitarian regime. In Sweden, however, the Estonians in exile began, in his view, especially emphatically to exhibit the negative traits of Estonianhood, "corrupted" by history - factiousness and incompetence of leadership (cf. Loorits 1953: 23ff, 66ff). Yet he never ceased to express a hope projected into the future, a hope that could become discordant with the conformation, cosmopolitan desires and eventually also lack of civic courage characteristic of a welfare society - becoming, in a word, an anachronism in an ever faster changing world where the old culture in its complexity had long ceased to exist. 
Science and myth are related as to their mode of genesis. The paradigms of the humanities, in particular, may often be narratives unavailing of conclusive positivist proof, mainly valued for diversifying the number of viewpoints available to a discipline. Loorits and Ariste with their ideals, however, belonged among positivist scholars in whose view the postmodernist abundance of possibilities in science and in the ways of modelling the truth based on it, might not have seemed correct. Furthermore, being students of culture, they also dealt with a search for (historical and geographical) archetypes of nationalism rather than its, say, functional formation or humanity. Thus, in the interests of easier comprehension, Estonianhood and Votianhood remained for them closed ecotypes rather than open objects. On the other hand, it is equally clear that the observation of an abstraction like people/nation and the processes going on within it will necessarily remain a schematic attempt revealing the seams of the researcher's arbitrary decisions.

\section{CONCLUSION}

The influence of Loorits's ideas on the Estonian and particularly that of Ariste on the Votian culture has been significant. Loorits ranks among the first authors whom the upholders and advocates of a particularly Estonian (non-European, non-Christian) culture feel obliged to quote in their talks and texts, having thus become a kind of monument or emblem. Ariste's message that Votianhood has a right to live, delivered to the last speakers of the language literally at the eleventh hour, has been equally successful. As ideologies, the narratives of both men have proved their functionality in certain contexts of time and space, and a post factum evaluation of their scientific and methodological competence may indeed appear even inappropriate.

Such a success of any ideologies as master narratives naturally presumes the existence of a corresponding demand or niche in social consciousness, whereas their aesthetic form need not play a decisive part in it. As noted above, this situation points to a crisis of self-definition in the society, a situation where the folk knowledge as a system has lost its value and validity, in the eyes of its transmitters, and is searching for a new way forward in the crisis. In the case of the 20th-century Votes, there is of course no need to doubt this kind of crisis, since by Ariste's day only remnants of the people had survived the shocks of the Second World War and made it back to their homeland since Stalin's death in 1953, which they found re-populated and distorted beyond recognition. What is graver is the instance of Loorits in the context of Estonian culture, testifying rather vividly that even after the era of awakening and of the 
foundation of nation state, the Estonians - declared to be a unified nation, as it were - still had unanswered questions about their cultural identity.

By calling into question the aspect of traditional culture in the national narrative, Loorits hit upon an important point of concern which might have been viewed as already overcome. Nevertheless, it seems that the transfer to a 'European culture', whereby only the more aesthetic and beautiful part of a partially disparaged peasant culture was picked out as décor for the nation state, had not from the very beginning satisfied all groups and thinkers. Thus, the narrative offered by Loorits was first and foremost a more scientifically pretentious answer for the vacuum left unfilled, in the Republic of Estonia, by Herderian national romanticism, the established Lutheran church associated with Germans, or other cultural symbioses. The questions Loorits posed with his constructions could not be fully developed because of the breaking out of the Second World War. Besides, the Soviet regime set new ideological tasks to folk culture - while national form was favoured, the Socialist content poured into it frightened off the oncoming generations, thus complicating the comprehensibility of the whole phenomenon, or the will to comprehend it, at all.

One can also be sure that Loorits's message was and is unacceptable to former and present-day cosmopolitans, frightening them off primarily with its accents on nationality and nationalism. Presumably, like in the early 20 th, so in the early 21 st century identifying oneself as landfolk and/or Finno-Ugrian and enunciating this identity (outside the moments of general national euphoria) requires more determination and courage of self-definition than is felt to be convenient against the present global background. When such issues are raised in the context of a small nation, they always seem to sound much more existential. It also seems that the only thing that can really endanger the Estonian identity's 'domestic peace' is hiding this problem, inherited from the age of awakening, behind a postmodernist plurality of free choices. Yet at the same time, it is the postmodern cultural situation that appears to create an arena where a polyphonic discussion of this situation, brought about by cultural shocks and ruptures, can go on. 


\section{ACKNOWLEDGEMENT}

This research was supported by the European Union through the European Regional Development Fund (Center of Excellence CECT).

\section{NOTES}

${ }^{1}$ For a thorough survey of the Votes, see Viikberg 2001.

2 If one wished to deliberately emphasize the Christian cultural context, it might be perhaps equally well stated here that the easternmost part of the Estonians began to leave the Orthodox sphere of influence during that period. In prehistoric times, the Baltic-Finnic peoples' main axis of trade and culture ran rather to the east of Lake Peipsi from Votian lands across the (present) Setu territories up to the Daugava estuary (cf. Valk 2000: 368-370, also Oinas 1979: 67ff).

3 Considering and calling oneselves 'folk of the land' (as well as 'humans') is a very wide-spread basis for many original and old ethnonyms (see, e.g., Grünthal 1997: 188). The use of 'landfolk' as an ethnonym in the self-definition of both the Votes and the Estonians of the 19th century has probably sprung from the same logic. Its later interpretation, however, need not be associated merely with social (town vs. country) or natural and geographic (coast vs. (in)land) oppositions, but may just as well involve also an ideological (opposing itself to a foreign occupying culture) or a religious (opposing itself to a foreign high religion) aspect (cf. Grünthal 1997: 187-191).

${ }^{4}$ A similar tendency may be observed between the Livonians of Daugava and Riga, as well as between the Muromians and Moscow, and naturally in the assimilation stories of many other small nations.

5 Thus, for instance, Dmitri Tsvetkov (1890-1930), the alumnus of the University of Tartu and Votian intellectual, consciously identified himself as a Russian, not a Vote (cf. Ernits 2004).

${ }^{6}$ For similar ideas, though more elaborate and presented in German, see Loorits 1957: $224-505$.

7 Of course, the expression "an old Vote" may contain a pejorative note, too.

8 This is what he has said, for instance, in a Votian language greeting on a postcard sent to an acquaintance (Arukask et al. 2001).

9 Loorits's popular book series, based on different folkloric texts, was titled EndisEesti elu-olu ('Life of One-Time Estonia'). 


\section{REFERENCES}

Ariste, Paul 1970. Vadja rahvaluule võlus. [Charmed by Votian Folklore.] Saaremaast Sajaanideni ja kaugemalegi. Tallinn: Valgus, pp. 89-99.

Ariste, Paul 2005. Vadja päevikud: 1942-1980. [Votian Diaries: 1942-1980.] Ed. by E.-H. Västrik. Tartu: Eesti Kirjandusmuuseum.

Arukask, Madis 2003. Paul Ariste ürgvadjaluse kontseptsioon ja Oudekki Figurova. [Paul Ariste's Concept of 'Primeval Votianism' and Oudekki Figurova.] Mäetagused, Vol. 21, pp. 222-230. Available at http://www.folklore.ee/tagused/nr21/ ariste.htm, accessed in Nov 2009.

Arukask, Madis; Raudalainen, Taisto \& Västrik, Ergo-Hart 2001. Akadeemik Ariste kaks armastust: vadjalased. [The Two Loves of Academician Paul Ariste.] Documentary. Tallinn: Estonian Television.

Ernits, Enn 2004. Dmitri Tsvetkovi keelekasutusest ja rahvustundest. [On Dmitri Tsvetkov's Language Use and Ethnic Identity.] In: K. Pajusalu \& J. Rahman (eds.) Kiil' ja hindätiidmine. Keel ja identiteet. Võro Instituudi toimõndusõq, No. 16, pp. 23-34.

Geertz, Clifford 1983. Local Knowledge. Further Essays in Interpretive Anthropology. New York: Basic Books, Inc. Publishers.

Grünthal, Riho 1997. Livvistä liiviin: itämerensuomalaiset etnonyymit. Helsinki: Suomalais-ugrilainen seura.

Jaago, Kalev \& Jaago, Tiiu 1996. See olevat olnud... Rahvaluulekeskne uurimus esivanemate lugudest. [It's Been Known to Have Happened: Folkloristic Study of the Tales of Ancestors.] Tartu: Tartu Ülikooli Kirjastus.

Jackson, John Hampden 1948 [1941]. Estonia. London: Allen \& Unwin.

Kolga, Margus; Tõnurist, Igor; Vaba, Lembit \& Viikberg, Jüri 2001 [1993]. The Red Book of the Peoples of the Russian Empire. Tallinn: NGO Red Book. Available at http://www.eki.ee/books/redbook, accessed in Nov 2009.

Laar, Mart 2006. Estonia's Way. Tallinn: Pegasus.

Loorits, Oskar 1932a. Eesti rahvausundi maailmavaade. [The Worldview in Estonian Folk Religion.] In: O. Loorits 1990. Eesti rahvausundi maailmavaade. Tallinn: Perioodika.

Loorits, Oskar 1932b. Estnische Volksdichtung und Mythologie. Tartu: Akadeemiline Kooperatiiv.

Loorits, Oskar 1933a. Koodi Jaan. In: O. Loorits 2000. Meie, eestlased. Eesti mõttelugu 35. Tartu: Ilmamaa, pp. 108-121.

Loorits, Oskar 1933b. Meie usund ja ühiskond, kristlus ja baltlus, juhid ja mass. [Our Religion and Society, Christianity and Baltic Identity, Leaders and the General Public.] In: O. Loorits 2000. Meie, eestlased. Eesti mõttelugu 35. Tartu: Ilmamaa, pp. 103-107.

Loorits, Oskar 1934. Ärgu kordugu Läti Henriku päevad! [May the Days of Henry of Livonia Never Return!] In: O. Loorits 2000. Meie, eestlased. Eesti mõttelugu 35. Tartu: Ilmamaa, pp. 145-149. 
Loorits, Oskar 1936. Kas oleme ida või lääne päritolu? [Are We of Eastern or Western Descent?] In: O. Loorits 2000. Meie, eestlased. Eesti mõttelugu 35. Tartu: Ilmamaa, pp. 157-163.

Loorits, Oskar 1938a. Eesti kultuuri struktuurist, orientatsioonist ja ideoloogiast. [On the Structure, Orientation, and Ideology.] In: O. Loorits 2000. Meie, eestlased. Eesti mõttelugu 35. Tartu: Ilmamaa, pp. 208-259.

Loorits, Oskar 1938b. Eesti rahvalaulu elutundest. [On the Sense of Life in Estonian Folk Songs.] In: O. Loorits 2000. Meie, eestlased. Eesti mõttelugu 35. Tartu: Ilmamaa, pp. 164-181.

Loorits, Oskar 1938c. Muinaseesti unarussejäänd põhiseadusest. [On the Neglected Constitution of Olden-Time Estonia.] In: O. Loorits 2000. Meie, eestlased. Eesti mõttelugu 35. Tartu: Ilmamaa, pp. 260-276.

Loorits, Oskar 1951. Eestluse elujõud. Iseseisvuslaste kirjavara 5. [The Vitality of Estonianhood.] Stockholm: Tõrvik.

Loorits, Oskar 1953. Pagulaskodude kasvatusmuresid. Iseseisvuslaste kirjavara 9. [Educational Problems in Refugee Homes.] Stockholm: Tõrvik.

Loorits, Oskar 1957. Grundzüge des estnischen Volksglaubens 3. Skrifter Utgivna av Kungl. Gustav Adolfs Akademien för Folklivsforskning 18:3. Uppsala \& Köpenhamn: Ludequistska Bokhandeln.

Loorits, Oskar 2000. Meie, eestlased. Eesti mõttelugu 35. [We, the Estonians.] Tartu: Ilmamaa.

Oinas, Felix J. 1979. Setu rahvaluulest. [On Setu Folklore.] In: Kalevipoeg kütkeis ja muid esseid rahvaluulest, mütoloogiast ja kirjandusest. [Kalevipoeg in Fetters; And Other Essays on Folklore, Mythology and Literature.] Toronto: Oma Press Ltd., pp. 65-76.

Rätsep, Huno 1989. Eesti keele tekkimise lugu. [The Formation of Estonian Language.] Akadeemia, Vol. 7, pp. 1503-1524.

Tedre, Ülo 1995. About the Life and Work of an Eccentric. Folk Belief Today. Tartu: Estonian Language Institute \& Estonian Literary Museum, pp. 457-468.

Valk, Heiki 2000. About the Early Medieval and Prehistoric Contacts of the Votians and the Daugava Livonians. Congressus Nonus Internationalis Fenno-Ugristarum. 7.-13.8. 2000 Tartu. Pars VIII. Dissertationes sectionum: Litteratura, Archaeologia \& Anthropologia \& Genetica \& Acta Congressus, pp. 365-374.

Viikberg, Jüri 2001 [1993]. The Votes. In: M. Kolga et al. (eds.) The Red Book of the Peoples of the Russian Empire. Tallinn: NGO Red Book, pp. 356-362. Available at http://www.eki.ee/books/redbook/votes.shtml, accessed in Nov 2009.

Västrik, Ergo-Hart 2005. Oskar Loorits: Byzantine Cultural Relations and Practical Application of Folklore Archives. In: K. Kuutma \& T. Jaago (eds.) Studies in Estonian Folkloristics and Ethnology: A Reader and Reflexive History. Tartu:Tartu University Press, pp. 203-215.

Västrik, Ergo-Hart 2007. Vadjalaste ja isurite usundi kirjeldamine keskajast 20. sajandi esimese pooleni. Alliktekstid, representatsioonid ja tõlgendused. [Descriptions of the Votian and Izhorian Religion from the Middle Ages to the First Half of the 
20th Century: Sources, Representations, and Interpretations.] Dissertationes folkloristicae Universitatis Tartuensis 9. Tartu: Tartu Ülikooli Kirjastus.

Öpik, Elina 1970. Vadjalastest ja isuritest XVIII sajandi lõpul. Etnograafilisi ja lingvistilisi materjale Fjodor Tumanski Peterburi kubermangu kirjelduses. [Votes and Izhorians in the Late 18th Century. Ethnographical and Linguistic Materials in the Descriptions of St Petersburg Guberniia by Feodor Tumanski.] Tallinn: Valgus. 